\title{
System for complex exhaust gas cleaning of internal combustion engine with water-fuel emulsion burning
}

\section{V.S. Kornienko}

Kherson Branch of Admiral Makarov National University of Shipbuilding, 44 Ushakov Avenue, Kherson, 73022, Ukraine

The necessity to fulfill all requirements of international organizations in the field of environmental protection, need to reduce heat loss in combustion of organic fuels, increasing economy and reliability of all elements of ship's power plant make it necessary to develop complex technology. The aim of study is to develop system for complex exhaust gas cleaning of internal combustion engine (ICE). For performing tasks in technology of proposed method, providing solutions to problems of improving economic efficiency, improvement of environmental indicators and reliability, it is envisaged 5 stages of technological process. At all stages conditions for appropriate running of physico-chemical processes in the next stage are created. Possibility of solving complex problems in proposed technology is ensured by combustion of water-fuel emulsion (WFE) with specifically recommended value of water content $W^{r}=30 \%$. When WFE is burnt with a water content of $30 \%$, the low-temperature corrosion intensity decreases, which allows to install a condensing heating surfaces in exhaust gas boilers. At these conditions an equimolar ratio of nitrogen oxides $\mathrm{NO}_{2}: \mathrm{NO}$ in gases is required, which is necessary to activate their absorption properties. When WFE is burnt with water content $W^{r}=30 \%$ the metal surface with a temperature below of dew point $\mathrm{H}_{2} \mathrm{SO}_{4}$ passivates. Experimental studies performed show that: $1 \mathrm{~m}^{2}$ of condensing surface absorbs $3.4 \mathrm{mg} / \mathrm{m}^{3}$ of $\mathrm{NO}_{x}$ and $0.89 \mathrm{mg} / \mathrm{m}^{3}$ of $\mathrm{SO}_{2}$, which makes it possible to decrease the $\mathrm{NO}_{x}$ concentration by 1.55 times and $\mathrm{SO}_{2}$ - in 1.5 times. There is a process of precipitation of toxic solid ash and soot particles: from $150 \ldots 170 \mathrm{mg} / \mathrm{m}^{3}$ (at outlet of ICE when WFE is burnt with $\mathrm{W}^{r}=30 \%$ ) to $70 \ldots 90 \mathrm{mg} / \mathrm{m}^{3}$ after the condensing surface. Consumption of water with alkaline properties decreases when $\mathrm{NO}_{x}, \mathrm{SO}_{2}, \mathrm{CO}_{2}$ concentration is reduced in front of scrubbers. Reducing pollution of heating surfaces increases the cleaning period of $E G B$ in 2.5 times. The using of complex system provides efficient exhaust gas cleaning at the level recommended by IMO.

Keywords: Water-fuel emulsion, Exhaust gas boiler, Condensing heating surface

doi:

(C) The Author(s) 2019. This article is an open access publication

This work is licensed under the Creative Commons Attribution 4.0 International License (CC BY) http://creativecommons.org/licenses/by/4.0/

\section{Introduction}

The necessity to fulfill all requirements of international organizations in the field of environmental protection, need to reduce heat loss in combustion of organic fuels, increasing economy and reliability of all elements of ship's power plant (SPP) make it necessary to develop complex technology. This complex technology is included stages: combustion of water-fuel emulsion (WFE), processes of heat-mass transfer, lowering of speed low-temperature corrosion (LTC), cleaning of gases from toxic ingredients. This requires an appropriate organization of physical and chemical processes that will enable the fulfillment of these tasks.

\section{Literature Review}

Methods for exhaust gases cleaning from toxic sulfur substances are known [1-3].

According to MAN experts [4], the requirements of IMO (the third level of $\mathrm{SO}_{\mathrm{x}}, \mathrm{NO}_{\mathrm{x}}$ emissions) can be fulfilled by following technologies: WFE, scavenge air moistening, exhaust gas recirculation, selective catalytic reduction (SCR).
The hybrid exhaust system was created as a result of joint development of Alfa Laval and Aalborg Industries [5] with participation of MAN diesel engines manufacturer based on Alfa Laval separators and existing Aalborg gas cleaning systems using, which used in tanker inert systems and was adapted for cleaning of diesel exhaust gases. This installation is hybrid, because it uses both sea and fresh water mixed with caustic soda. When installation was operated in seawater it is possible to remove $98 \%$ of sulfur substances. When installation was operated in fresh water, more than $99 \%$ of these substances remove. In addition, up to $80 \%$ of solid particles are captured.

In hybrid Alfa Laval and Aalborg Industries cleaning system, the first cleaning stage is considered exhaust gas boiler (EGB) in which exhaust gases are cooled from $350{ }^{\circ} \mathrm{C}$ to $160 \ldots 180{ }^{\circ} \mathrm{C}$. There is pollution of EGB surfaces that can be considered as a cleaning stage from solid particles. At the second cleaning stage, due to use of Venturi scrubber, water injection continues to reduce the exhaust gas temperature and to remove solid particles due to their moisture.

Only cleaning of $\mathrm{NO}_{\mathrm{x}}$ by expensive catalysts and entering of urea and ammonia solution as reducing agent is carried out in SCR [6, 7]. The SCR system (only $\mathrm{NO}_{\mathrm{x}}$ 
absorption from exhaust gases) must be accompanied by scrubber $\mathrm{SO}_{\mathrm{x}}$ cleaning technology.

The radical and rather simple way of sulfur substances reducing is exhaust gases cleaning with help of scrubber technologies, where $\mathrm{SO}_{\mathrm{x}}, \mathrm{NO}_{\mathrm{x}}, \mathrm{CO}_{2}$ and solid particles of gas stream are absorbed by seawater.

Since only higher nitrogen oxides $\mathrm{NO}_{\mathrm{x}}$ are better absorbed by water to form nitrogen and nitrous acids, $\mathrm{NO}_{\mathrm{x}}$ absorption by water should be carried out with pre oxidation of $\mathrm{NO}$ to $\mathrm{NO}_{2}$ and $\mathrm{N}_{2} \mathrm{O}_{3}$. The authors $[8,9]$ decide on quickly oxidation of $\mathrm{NO}$ in $\mathrm{NO}_{2}$ using ozone as an oxidizer. Ozone in the event of an accidental release (according to the authors) is quickly transformed into molecular oxygen and does not pose a danger to atmosphere. The mechanism of chemical processes of this cleaning method is based on oxidation of $\mathrm{NO}$ to $\mathrm{NO}_{2}$, with following absorption of obtained higher oxides by water.

In [1] the $\mathrm{CSNO}_{\mathrm{x}}$ exhaust gas cleaning system is considered, whith developed by Ecospec Global Technology. This system unlike the previously considered technologies allows more intensive and simultaneous reduction of three toxic substances content $-\mathrm{SO}_{\mathrm{x}}, \mathrm{CO}_{2}$ and $\mathrm{NO}_{\mathrm{x}}$.

The use of $\mathrm{CSNO}_{\mathrm{x}}$ scheme for exhaust gas cleaning after 6S50MC, showed that with content toxic substances at outlet of internal combustion engine (ICE) $846.05 \mathrm{ppm}$ of $\mathrm{SO}_{2}, 709.26 \mathrm{ppm}$ of $\mathrm{NO}_{\mathrm{x}}$ and 3,99\% of $\mathrm{CO}_{2}$, at scrubber exit, the same ingredients content was $10.75 \mathrm{ppm}$ of $\mathrm{SO}_{2}$, $243.11 \mathrm{ppm}$ of $\mathrm{NO}_{\mathrm{x}}$ and $0.93 \%$ of $\mathrm{CO}_{2}$. The emission of the main harmful substances decreased in the following ratio: $\mathrm{SO}_{2}-98.7 \%, \mathrm{NO}_{\mathrm{x}}-65.7 \%, \mathrm{CO}_{2}-76.7 \%$ [1].

In prototype $\mathrm{CSNO}_{x}$ technology, only possibility of increasing water absorption capacity as an absorbent is considered. The possibility of increasing exhaust gases absorption capacity as an absorbent is not considered at all. The questions of gas path reliability of SPP elements, the possibility of deepening the exhaust gases heat utilization of ICE by reducing their temperature below the dew point temperature sulfuric acid $\left(130^{\circ} \mathrm{C}\right)$ and water vapor (below $48{ }^{\circ} \mathrm{C}$ ) and the capture of solid particles into scrubbers are not considered at all

The aim of study is to develop a system for complex exhaust gas cleaning of internal combustion engine.

The basis of technology are tasks: 1) increasing of exhaust gases cleaning depth from toxic substances; 2) intensification of $\mathrm{SO}_{2}, \mathrm{CO}_{2}, \mathrm{NO}_{\mathrm{x}}$ absorption by water; 3) increasing of exhaust gases absorption activity in relation to $\left.\mathrm{NO}_{\mathrm{x}}, \mathrm{SO}_{2}, \mathrm{CO}_{2} ; 4\right)$ reduction of solid ash and soot particles emissions as a result of combustion; 5) decreasing of LTC intensity; 6) reduction of heat losses with exhaust gases by condensing surface installing at outlet of EGB.

\section{Research Methodology}

Possibility of solving complex problems in proposed technology is ensured by combustion of WFE with specifically recommended value of water content $\left(W^{\mathrm{r}}=30 \%\right)$. Such WFE composition substantially affects not only running of thermal and physicochemical processes along the entire path of fuel combustion aggregates (starting from combustion zone and to cut of flue), but also directs them in the required direction.

For performing tasks in technology of proposed method, providing solutions to problems of improving economic efficiency, improvement of environmental indicators and reliability, it is envisaged 5 stages of technological process:

1) combustion of appropriate quality WFE with water content about $W^{\mathrm{r}}=30 \%$ leads to formation of equimolar ratio $\mathrm{NO}_{2}$ : $\mathrm{NO}$ in exhaust gases at outlet of combustion zone (as confirmed by patent [10] and providing LTC reduction), as well as reducing $\mathrm{NO}_{\mathrm{x}}, \mathrm{SO}_{2}, \mathrm{CO}_{2}$ emissions;

2) installation of condensing surfaces, on which conditions are created for passivation of metal and a sharp decrease LTC intensity, as well as conditions from side of gases and in condensate to intensify $\mathrm{NO}_{\mathrm{x}}, \mathrm{SO}_{2}, \mathrm{CO}_{2}$ absorption;

3) continuation of absorption intensification on condensing surfaces of gas flues to scrubber part (providing conditions for reliable operation of their metal) or maintaining temperature of metal of these gas flues above the dew point temperature $\mathrm{H}_{2} \mathrm{SO}_{4}$ without $\mathrm{NO}_{\mathrm{x}}, \mathrm{SO}_{2}, \mathrm{CO}_{2}$ absorption, but ensuring reliability of work (at low LTC level);

4) application of intensive scrubber technologies with use of processes for activating $\mathrm{NO}_{\mathrm{x}}, \mathrm{SO}_{2}, \mathrm{CO}_{2}$ absorption;

5) protection of gas flues metal after scrubbing part.

At all stages conditions are created not only for running of processes that ensure fulfillment of stage tasks, but also necessary conditions for proper running of physicochemical processes in next stage are provided.

\section{Results}

Research is shown, that primary and decisive factor for solving problems in the development of complex system for reducing environmental indicators, corrosion and heat losses, improving economic efficiency is organization of WFE burning process in ICE (based on sulfur fuels) with water content about $30 \%$. When $1 \mathrm{~kg}$ of WFE was preparation, water and fuel were mixed in ratio of $300 \mathrm{~g}$ of water and $700 \mathrm{~g}$ of fuel, which means water content WFE $W^{\mathrm{r}}=30 \%(30 \%$ water in $1 \mathrm{~kg}$ WFE or water ratio $300 / 700$ $=42,86 \%$ ).

For fulfill the problem of exhaust gases absorption properties activating, it is necessary to provide an equimolar (or close to it) ratio of $\mathrm{NO}_{2}$ : $\mathrm{NO}$ in gases (first stage). As our scientific studies have shown, this ratio is naturally created at the end of WFE combustion zone with water content $W^{\mathrm{r}}=30 \%$ due to the effect of intense turbulence. There is created in micro drops of WFE in active burning zone.

Under these conditions, the metal surface with temperature below the dew point temperature $\mathrm{H}_{2} \mathrm{SO}_{4}$ passivates, and therefore there is a possibility a significant decrease of condensing surface LTC, which is confirmed by obtained patent [10].

This makes it possible to install condensing surface in EGB outlet after ICE with a temperature below the dew point temperature $\mathrm{H}_{2} \mathrm{SO}_{4}$ (wall temperature can be maintained in the range $\left.130 \ldots 70{ }^{\circ} \mathrm{C}\right)$. As a result, all surface covered with a layer of wet (from condensation of acid) pollution. Moreover, sulfuric acid concentration in this surface temperature range is also natural (due to corresponding physical and chemical processes) set at a level of $57 \%$, which shows the maximum $\mathrm{SO}_{2}$ absorption (Fig. 1). 


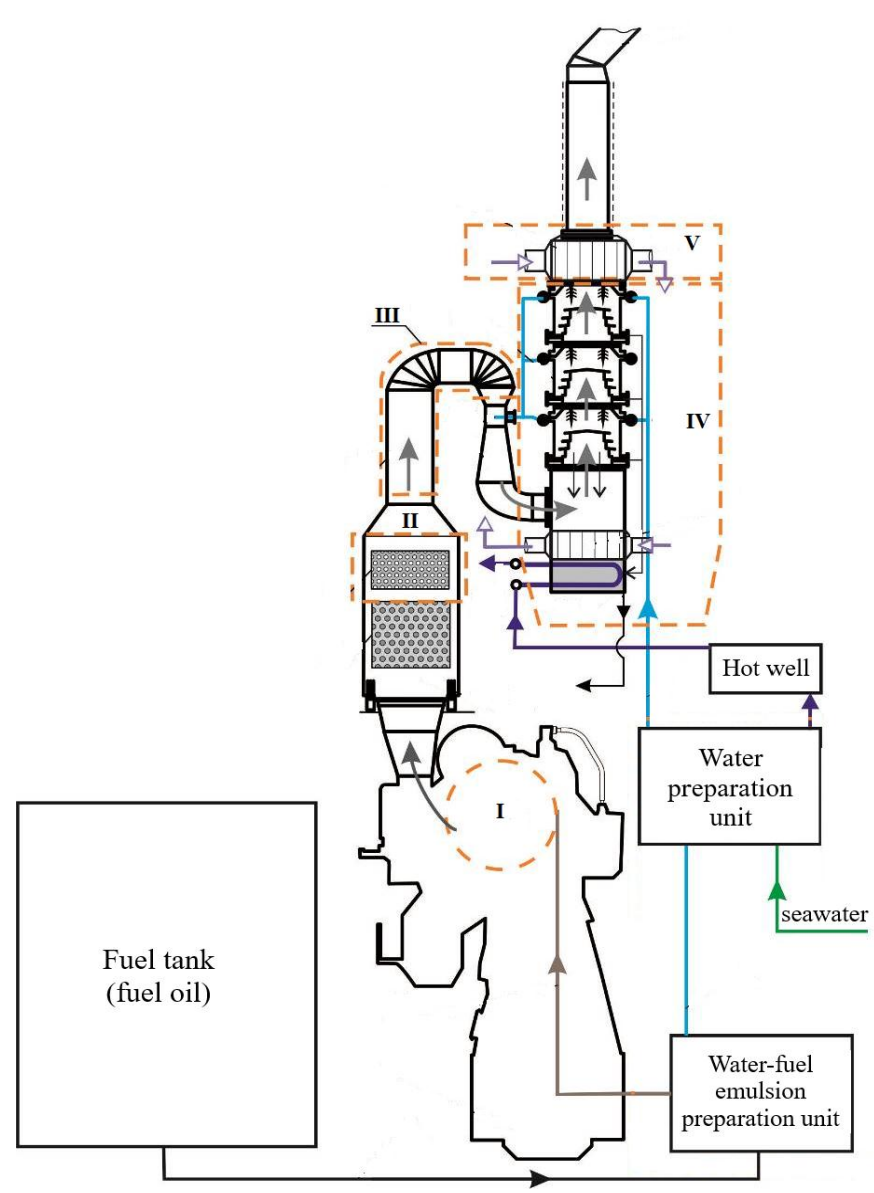

$I$ - reducing concentration of toxic substances and solids in gases when WFE is burnt with water content $30 \%$; II adsorption processes occurring on condensing surfaces of exhaust gas boilers; III - processes occurring on condensing surfaces of gas flues; IV - scrubber gas cleaning technology; V-gas dry

Figure 1 - A scheme of system for complex gas cleaning method and stages of cleaning

The presence of pollutions on these surfaces is influenced on intensity of absorption processes in condensate on condensing surfaces in EGB and gas flues. In pollution layer moisturizing by acid, an additional process of vapor and moisture adsorption by coke and sooty particles on condensing surface will take place. Therefore, it is important how pollution processes of heating surfaces and gas flues during burning of WFE are developed. In pollution layer moisturizing by acid, there is an intensification of $\mathrm{NO}_{\mathrm{x}}$ and $\mathrm{SO}_{2}$ absorption process by sulfuric acid solution, which is present in pollutions. Additionally, adsorption of these gases by ash and especially soot particles takes place.

Ensuring $\mathrm{NO}_{\mathrm{x}}, \mathrm{SO}_{2}$ and $\mathrm{CO}_{2}$ absorption by sulfuric acid condensate on EGB condensing surfaces is considered as second stage of exhaust gases cleaning from toxic substances.

After condensing surface installed at outlet of EGB, exhaust gases enter in gas flue. After condensing surface, the acid vapor concentration in gases will be lower and, accordingly, it will decrease its the dew point temperature
$\mathrm{H}_{2} \mathrm{SO}_{4}$, which facilitates protection of metal gas flue after condensing heating surface.

Important for following stages of exhaust gas cleaning is that during physical and chemical processes in condensate and pollution layer on condensing surfaces, not only concentration of $\mathrm{NO}_{\mathrm{x}}$ decreases, and that it is important equimolar ratio $\mathrm{NO}: \mathrm{NO}_{2}$ in gases flow after EGB condensing heating surface. This means that possibility in presence of $\mathrm{H}_{2} \mathrm{SO}_{4}$ condensate on internal metal surface of gas flue is possible to ensure passivation of metal surface of gas flue in subsequent process of exhaust gas cleaning from $\mathrm{NO}_{\mathrm{x}}, \mathrm{SO}_{2}$ by same mechanism as in previous condensing heating surfaces at outlet of EGB.

Thus, above-mentioned processes provide third stage of exhaust gas cleaning.

To ensure the final cleaning of exhaust gases from $\mathrm{NO}_{\mathrm{x}}$ and $\mathrm{SO}_{2}$ to the level planned by IMO regulations, it is necessary to use scrubber technologies $[11,12]$.

In order to clean exhaust gases with the help of scrubber technologies after gas outlet of EGB, a scrubber - a wet scrubber of successive gas cleaning from $\mathrm{SO}_{2}, \mathrm{NO}_{\mathrm{x}}$ and $\mathrm{CO}_{2}$ is installed in gas pipeline during burning of sulfur fuels (fourth stage).

In the case of WFE combustion based on sulfur fuel, when largest amount of $\mathrm{SO}_{2}, \mathrm{NO}_{\mathrm{x}}$ is produced, it is recommended to install a scrubber with a nozzle, which is possible and must be performed from non-corrosive material (ceramics, acid-resistant plastics). The nozzle is irrigated by the same solution of catholyte, which activated in cavitator for intensify absorption process. The temperature of this catholyte should be at temperature of seawater - necessarily below the dew point temperature of water vapor located in exhaust gases (when WFE is burnt with $W^{\mathrm{r}}=30 \%$ its value is at $48 \ldots .50{ }^{\circ} \mathrm{C}$ depending from water content of emulsion). In this case, the condensation of water vapor in gases will be provided, which will (in addition to absorption heat) be accompanied by release of a large amount of heat. As a result, water at outlet of nozzle after mixing with gas flow is heated up to $80 \ldots 90{ }^{\circ} \mathrm{C}$ (temperature level is provided by adjusting flow rate of catholyte to irrigation of nozzle with required level of $\mathrm{NO}_{\mathrm{x}}$, $\mathrm{CO}, \mathrm{SO}_{2}, \mathrm{CO}_{2}$ absorption). By providing the appropriate alkalinity level of water that goes to irrigation and neutralization of acidity, solution at outlet of nozzle will be neutral.

Due to substantial decrease of exhaust gases temperature (below $50^{\circ} \mathrm{C}$ ) in scrubbers after ICE and EGB, in which there are water vapors with acid properties corresponds to amount of water vapor, it is possible under these conditions to condense them on internal surface of gas flue after scrubbers.

Since the gases temperature is near to the dew point temperature of water vapor, work conditions of gas flues metal will deteriorate as a result of condensation of these vapors (although their amount will be substantially reduced after condensation in scrubber). Therefore, it is necessary to apply a drying of wet exhaust gases.

The drying of wet gases after scrubber is carried out by installing dryer (air heater). In tubes of these heat exchanger a solution layer is moved, and air is moved across pipes outside.

On Fig. 2 the results of experimental studies are shown. 


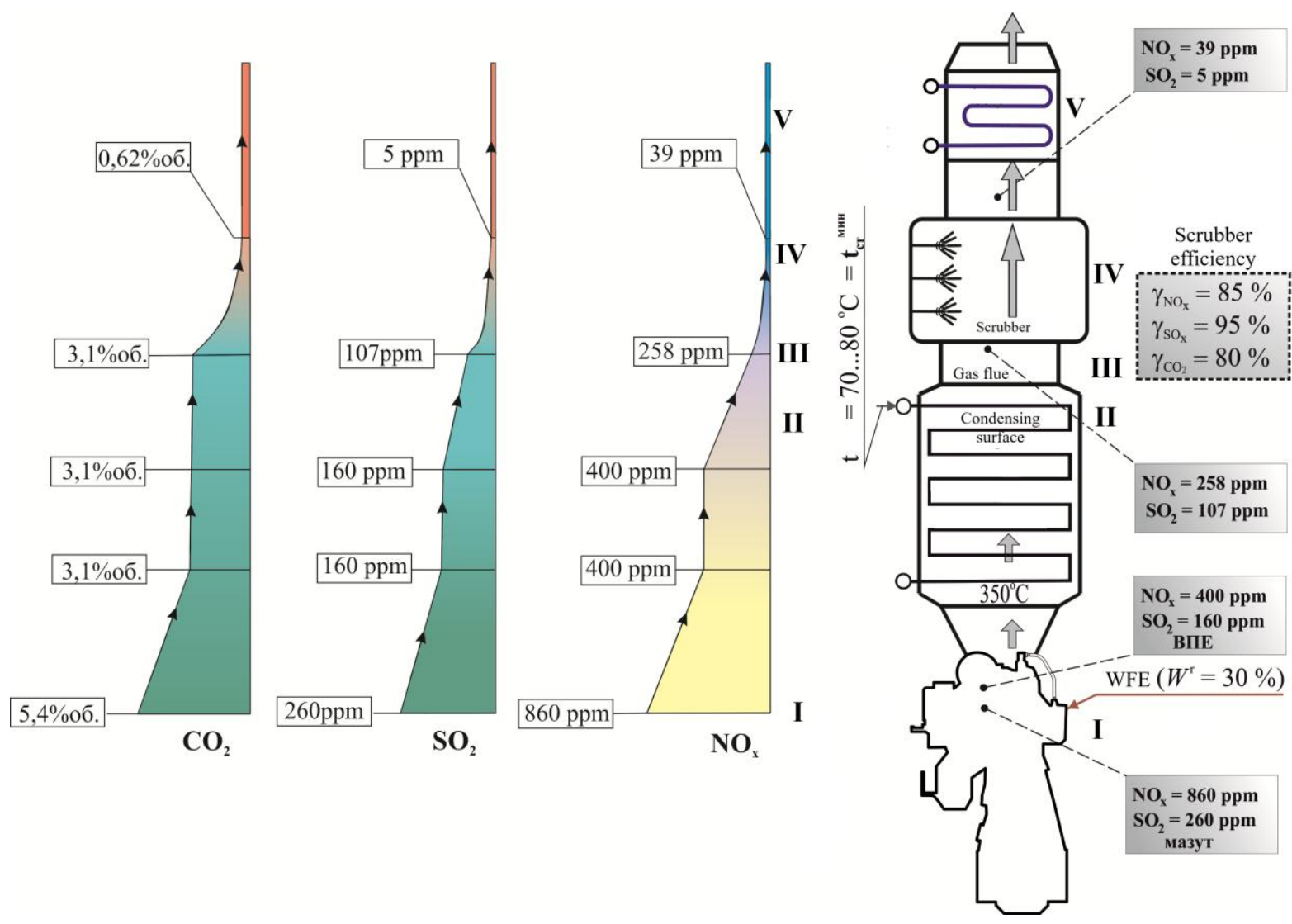

Figure 2 -Reduction of harmful substances emissions due to using WFE and application of scrubber technology

Experimental studies performed show that: $1 \mathrm{~m}^{2}$ of condensing surface absorbs $3.4 \mathrm{mg} / \mathrm{m}^{3}$ of $\mathrm{NO}_{\mathrm{x}}$ and 0.89 $\mathrm{mg} / \mathrm{m}^{3}$ of $\mathrm{SO}_{2}$, which makes it possible to decrease the $\mathrm{NO}_{\mathrm{x}}$ concentration by 1.55 times and $\mathrm{SO}_{2}$ in 1.5 times. It is important that additionally there is a process of precipitation of toxic solid ash and soot particles: from $150 \ldots 170 \mathrm{mg} / \mathrm{m}^{3}$ (at outlet of ICE when WFE is burnt with $W^{\mathrm{r}}=30 \%$ ) to $70 \ldots 90 \mathrm{mg} / \mathrm{m}^{3}$ after condensing surface.

\section{Conclusions}

When WFE is burnt with a water content of $30 \%$, the low-temperature corrosion intensity decreases, which allows to install a condensing heating surfaces in EGB.

The installation of a condensing heating surface reduces the content in gases of $\mathrm{NO}_{\mathrm{x}}$ by $55 \%, \mathrm{SO}_{2}$ - by $50 \%$, and content of solid particles - in 3 times.

Reducing pollution of heating surfaces increases the cleaning period of EGB in 2.5 times.

The using of complex system provides exhaust gas cleaning at the level recommended by IMO.

\section{References}

1. Ecospec CSNOxTM Broshure (2013). Available at: http://www.ecospec.com/upload/brochurepdf/67_uaez4cere 8bt2axq15896mgz76wsbasv.pdf (Accessed: 04.09.2018).

2. Landet, R.D. (2010). PM emissions and NOx reduction due to water in fuel emulsions in marine diesel engines. Norwegian University of Science and Technology, Department of Marine Technology, Student thesis. Available at: http://ntnu.diva-portal.org/smash/get/diva2:37 5078/FULLTEXT01 (Accessed: 04.09.2018)/

3. Andreasen, A., Nyggard, K.B. (2011). Water-in-fuel emulsion as marine engine fuel for reduced NOx and particulate emissions. The Danish Environmental Protection Agency, Environmental Project, 1380, 75 p. Available at: http://www2.mst.dk/udgiv/publications/2011/ 08/97887-92779-30-4.pdf (Accessed: 04.09.2018).

4. Skeltved, O. (2010). CIMAC NMA. Available at: http://sintef.net/upload/MARINTEK/CIMAC2010/MAN\% 20Ole\%20Skeltved.pdf (Accessed: 04.09.2018).

5. PureSOx Exhaust gas cleaning (2013). Available at: http://www.alfalaval.com/industries/marine/oiltreatment/Do cuments/PureSOx\%20product\%20brochure.pdf (Accessed: 04.03.2018).

6. Voznickij, I.V., Punda, A.S. (2008). Sudovye dvigateli vnutrennego sgoranija. Moskow, 2, $470 \mathrm{p}$.

7. Gorbov, V.M. (2010). Enciklopediia sudovoi energetiki: uchebnik. Nikolaev, $624 \mathrm{p}$.

8. Ezhov, V.S., Kormilicyn, V.I. (2008). Mehanizm processov okislenija oksidov azota pri sinhronnoj ochistke i utilizacii gazoobraznyh vybrosov. Energosberezhenie $i$ vodopodgotovka, 3, 68-70.

9. Ezhov, V.S., Kormilicyn, V.I. (2008). Mehanizm processov pogloshhenija oksidov azota pri sinhronnoj ochistke i utilizacii gazoobraznyh vybrosov. Energosberezhenie $i$ vodopodgotovka, 6, 65-69. 
10. Gorjachkin, V.Ju., Gorjachkin, A.V., Akimov, O.V. ta in. (2012). Patent UA 99408. Sposib zahistu metalu niz'kotemperaturnih poverhon' nagrivu kotla vid sirchanokislotnoï koroziï. Opublikovano 10.08.2012.

11. Hansen, J.P. (2012). Exhaust Gas Scrubber Installed Onboard MV Ficaria Seaways: Public Test Report. The Danish Environmental Protection Agency, Environmental Project, 1429, 30 p. Available at: http://www2.mst.dk/ Ud giv/publications/2012/06/978-87-92903-28-0.pdf (Accessed: 04.09.2018).
12. Kjølholt, J., Aakre, S., Jürgensen, C., Lauridsen, J. (2012). Assessment of possible impacts of scrubber water discharges on the marine environment, The Danish Environmental Protection Agency, Environmental Project, 1431, 92 p. Available at: http://www2.mst.dk/Udgiv/ publications/2012/06/978-87-92903-28-0.pdf (Accessed: 01.04.2018).

\title{
Комплексна система очищення відпрацьованих газів двигунів внутрішнього згоряння при спалюванні водопаливних емульсій
}

\section{В.С. Корніснко}

Національний університет кораблебудування ім. адм. Макарова, Херсонська філія, пр. Ушакова, 44, м. Херсон, 73022, Україна

\begin{abstract}
Необхідність виконання всіх вимог міжнародних організацій в галузі охорони навколишнього середовища, необхідність зниження теплових втрат при спалюванні органічних палив, підвищення економічності та надійності всіх елементів суднової енергетичної установки зумовлюють необхідність розробки складних технологій. Метою дослідження є розробка системи комплексного очищення відпрацьованих газів двигунів внутрішнього згоряння. Для виконання завдань запропонованого способу, щчо забезпечує вирішення проблем підвищення економічної ефективності, поліпшення екологічних показників та надійності, передбачено 5 етапів технологічного процесу. На всіх етапах створюються умови для відповідного проходження фізико-хімічних проиесів у наступному етапі. Можливість вирімення складних завдань у запропонованій технологіі забезпечується спалюванням водопаливної емульсї (ВПЕ) із спеціально рекомендованим значенням вмісту води $W^{r}=30 \%$. При цих умовах забезпечується еквімолярне співвідночення оксидів азоту $\mathrm{NO}_{2}: \mathrm{NO}_{6}$ газах необхідне для активізаиії їх абсорбиійних властивостей. При спалюванні ВПЕ з водовмістом $W^{r}=30 \%$ проходить пасивація поверхні металу з температурою нижче температури точки роси пари $\mathrm{H}_{2} \mathrm{SO}_{4}$. При спалюванні ВПЕ з водовмістом 30\% знижується інтенсивність низькотемпературної корозії, щзо дозволяє встановити конденсачійні поверхні нагріву в утилізаційному котлі. Проведені експериментальні дослідження показали, щя: $1 \mathrm{M}^{2}$ конденсаційної поверхні поглинає $3,4 \mathrm{Mz} / \mathrm{M}^{3} \mathrm{NO}_{x}$ i $0,89 \mathrm{Mz} / \mathrm{M}^{3} \mathrm{SO}_{2}$, щзо дозволяє знизити кониентрацію $\mathrm{NO}_{x}$ в 1,55 рази, а $\mathrm{SO}_{2}$ - в 1,5 рази. Відбувається процес осадження твердих зольних $і$ сажових

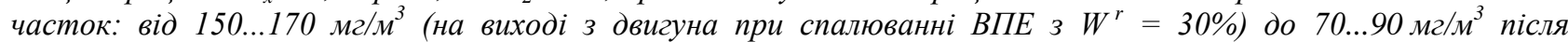
конденсаційної поверхні. Зменшення забруднення поверхонь нагріву збільшує період між очищеннями утилізаційних котлів у 2,5 рази. Використання комплексної системи забезпечує очищення газів до рівня, рекомендованого IМО.
\end{abstract}

Ключові слова: Водопаливна емульсія, Утилізаційний котел, Конденсаційна поверхня нагріву

\section{Література}

1. Ecospec CSNOxTM Broshure. [Електронний ресурс] Режим доступу: http://www.ecospec.com/upload/brochure pdf/67_ua ez4cere8bt2axq15896mgz76wsbasv.pdf (Дата звернення: 04.09.2018).

2. Landet, R.D. PM emissions and NOx - reduction due to water in fuel emulsions in marine diesel engines. Norwegian University of Science and Technology, Department of Marine Technology, Student thesis. - 2010. Режим доступу: http://ntnu.diva-portal.org/smash/get/ diva 2:375078/FULLTEXT01 (Дата звернення: 04.09.2018).

3. Andreasen, A., Nyggard, K.B. Water-in-fuel emulsion as marine engine fuel for reduced NOx and particulate emissions. The Danish Environmental Protection Agency, Environmental Project. - No.1380. - 2011. - 75 p. Режим доступу: http://www2.mst.dk/udgiv/publications/2011/08/ 978-87-92779-30-4.pdf (Дата звернення: 04.09.2018).
4. Skeltved, O. CIMAC NMA. Режим доступу: http://sintef.net/upload/MARINTEK/CIMAC2010/MAN\% 20Ole\%20Skeltved.pdf (Дата звернення: 04.09.2018).

5. PureSOx Exhaust gas cleaning. Режим доступу: http://www.alfalaval.com/industries/marine/oiltreatment/Do cuments/PureSOx\%20product\%20brochure.pdf (Дата звернення: 04.03.2018).

6. Возницкий И.В. Судовые двигатели внутреннего сгорания [Текст] / И.В. Возницкий, А.С. Пунда. - М. : Моркнига, 2008. - Том 2.- 470 с.

7. Горбов В.М. Энциклопедия судовой энергетики: Учебник [Текст] / В.М. Горбов. - Николаев, НУК, 2010. $-624 \mathrm{c}$.

8. Ежов В.С. Механизм процессов окисления оксидов азота при синхронной очистке и утилизации газообразных выбросов [Текст] / В.С. Ежов, В.И. Кормилицын // Энергосбережение и водоподготовка.2008. - №3. - C. 68-70. 
9. Ежов В.С. Механизм процессов поглощения оксидов азота при синхронной очистке и утилизации газообразных выбросов [Текст] / В.С. Ежов В.И., Кормилицын // Энергосбережение и водоподготовка. 2008. - №6. - C. 65-69.

10. Горячкін В.Ю. Спосіб захисту металу низько температурних поверхонь нагріву котла від сірчанокислотної корозії / В.Ю. Горячкін, А.В. Горячкін, О.В. Акімов та ін. / Патент UA № 99408, МПК С23F 11/10, F22B 37/00, F23J 15/00. Опубліковано 10.08.2012.

11. Hansen, J.P. Exhaust Gas Scrubber Installed Onboard MV Ficaria Seaways: Public Test Report. The Danish Environmental Protection Agency, Environmental Project.
- No.1429. - 2012. - 30 p. Режим доступу: http://www2. mst.dk/Udgiv/publications/2012/06/978-87-92903-28-0.pdf (Дата звернення: 04.09.2018).

12. Kjølholt, J., Aakre, S., Jürgensen, C., Lauridsen, J. Assessment of possible impacts of scrubber water discharges on the marine environment, The Danish Environmental Protection Agency, Environmental Project. - No.1431. - 2012. - 92 p. Режим доступу: http://www2. mst.dk/Udgiv/publications/2012/06/978-87-92903-28-0.pdf (Дата звернення: 01.04.2018).

Отримана в редакції 03.01.2019, прийнята до друку 05.02.2019 